\title{
Real Exchange Rate Dynamics in Model with Habit Formation
}

Yusuf Ömür Yılmaz*

University of Mardin Artuklu

\begin{abstract}
Much empirical evidence indicates that real exchange rates display hump-shaped dynamics. However, modern open-economy models hardly predict this behavior. In this paper, we develop a small open-economy model by extending the habit persistence parameter. This model helps us to understand real exchange rate dynamics in response to a persistent monetary policy shock under alternative monetary policy rules in an incomplete market with a risk-sharing wedge. Results indicate that incorporating a higher habit persistence parameter into the model helps replicate the hump-shaped dynamics of real exchange rates under the standard and inertial Taylor Rules. The same analyses are repeated featuring an incomplete market with portfolio adjustment cost, yielding similar results except in initial periods to previous analyses for the standard Taylor rule.

Keywords: Habit Persistence, Small Open Economy, Real Exchange Rate, Purchasing Power Parity Puzzle, Delayed Overshooting Puzzle

JEL Classification: E32, F31, F41
\end{abstract}

\section{Alışkan Formasyonlu Modelde Reel Döviz Kuru Dinamiği}

\section{Özet}

Ampirik bulgular, reel döviz kurlarının hörgüç şeklinde dinamikler sergilediğini göstermektedir. Fakat modern açık ekonomi modelleri çoğu zaman bu dinamikleri tahmin edememektedir. $\mathrm{Bu}$ çalışmada, alışkanlık sürekliliği parametresi kullanılarak küçük açık ekonomi modeli geliştirilmiştir. Geliştirilen model, risk paylaşım takozlu eksik bir piyasada alternatif para politikası kuralları altında standart para politikası şokuna cevaben reel döviz kuru dinamiklerini anlamamıza yardımcı olmuştur. Elde edilen sonuçlar, modele daha yüksek bir alışkanlık sürekliliği parametresinin dahil edilmesinin, standart ve ataletli Taylor kuralları altında reel döviz kurlarının hörgüç şeklindeki dinamiklerinin tahmin edilmesine yardımcı olduğunu göstermektedir. Aynı analizler, portföy uyarlama maliyetli eksik bir piyasada tekrarlanmış ve standart Taylor kuralında ilk dönemler hariç önceki analizlere benzer sonuçlar bulunmuştur.

Anahtar Kelimeler: Alışkanlık Sürekliliği, Küçük Açık Ekonomi, Reel Döviz Kuru, Satın Alma Gücü Paritesi Bilmecesi, Gecikmiş Siçrama Bilmecesi

JEL Sinıflandırmasi: E32, F31, F41

\footnotetext{
* Yusuf Ömür Yılmaz, Research Assistant Dr., Department of Economics, University of Mardin Artuklu, Mardin, Turkey, Email: yusufomuryilmaz@ artuklu.edu.tr, Tel. Number: +904822134002. ORCID: 0000-0001-9486-1618
} 
$\mathrm{E}$ mpirical studies indicate that real exchange rates are highly volatile and persistent in developed economies. However, modern open-macroeconomic models often fail to replicate these empirical features. Rogoff (1996) calls this phenomenon the Purchasing Power Parity (PPP) Puzzle. Although incorporating price stickiness into a model can help replicate highly volatile real exchange rate (RER) dynamics, this approach unfortunately lacks the persistence of real exchange rates (Chari et al., 2002), particularly regarding hump-shaped dynamics ${ }^{1}$. Features have been incorporated into various models to overcome this issue: alternative sources of monetary policy shock (Engel, 2019; Benigno, 2004), different types of shock (Steinsson, 2008), heterogeneity in price stickiness (Carvalho \& Nechio, 2011), and heterogeneity in price stickiness and the positive trend inflation rate (Cooke \& Kara, 2018). Two studies (Carvalho \& Nechio, 2011; Cooke \& Kara, 2018) found that extending these features into models can help obtain a more persistent real exchange-rate. In other studies, the real exchange rates' persistence depends on the type of shock and the source of persistence.

There is also another important feature, habit persistence, whose effects on real exchange rate dynamics are discussed. Steinsson (2008) argues how models featuring habit formation change the dynamics of the real exchange rate, stating that habit persistence in consumption does not lead to hump-shaped dynamics in real exchange rates under monetary policy shocks because the dynamics of marginal utility are not hump-shaped ${ }^{2}$. Nam (2015) discusses how habit formation affects real exchange rate dynamics in a two-open economy New Keynesian model. Nam (2015) reports findings that support Steinsson's statement. He attributes the lack of hump-shaped real exchange-rate dynamics led by habit persistence to the complete market.

The novel contribution of this paper to the discussion is to analyze the effects of habit persistence on real exchange-rate dynamics, particularly in a small open economy model with an incomplete feature. We follow the type of external habit formation utilized in Abel (1990). Unlike previous studies (Steinsson, 2008; Nam, 2015), the ability of the domestic economy to affect foreign economies is limited. Thus, any incidence occurring in the domestic economy negligibly affects the world economy. The effects of a foreign country's variables on domestic variables, particularly the real exchange rate, caused by domestic shocks are bounded. Therefore, we can claim that the real exchange rate is solely driven by the domestic economy. We expand the standard small open economy in Gali \& Monacelli (2005) with the habit formation feature. Although we assume a complete market assumption in the model economy, we relax the international risk sharing condition by reducing it to the one in Gali \& Monacelli (2005) to provide an ad-hoc time varying risk sharing wedge to the model in the analysis section $^{34}$. For a more realistic economic environment, our model follows Ascari \& Sbordone (2014) and Ascari \& Ropele (2009) in extending positive trend inflation rate and inflation rate indexation.

We analyze and discuss how habit persistence parameter (the persistence coefficient of habit formation $)^{5} h$ affects the real exchange rate dynamics under the standard Taylor Rule. Results indicate that a higher habit-persistence parameter $h$ leads to more persistent real exchange-rate dynamics and decreases the impact effect of monetary policy shock on the real

\footnotetext{
${ }^{1}$ See Huizinga (1987), Eichenbaum \& Evans (1995), Cheung \& Lai (2000), Steinsson (2008), Kim et al. (2017), Grilli \& Roubini (2006), and Scholl \& Uhlig (2008) for more information on hump-shaped dynamics of real exchange rates.

${ }^{2}$ Svensson (2008) employs a two-open economy model in the paper.

${ }^{3}$ The reason why not to use standard types of incomplete market cited in the literature is analytical tractability.

${ }^{4}$ See Berger et al. (2019) for discussion on risk-sharing wedges.

${ }^{5}$ The habit persistence parameter and the persistence coefficient of habit formation are used interchangeably in this paper.
} 
exchange rate in absolute terms. Moreover, we compare the impulse response functions of the real exchange rate both in the presence and absence of habit formation under alternative monetary policy rules-standard and inertial Taylor Rules. We find that the model generates hump-shaped dynamics in the real exchange rate in the presence of considerably higher habit formation under both rules. Moreover, the model generates quasi hump-shaped dynamics in the real exchange rate in the presence of moderately high and low habit persistence parameters under both rules. It leads to quasi hump-shaped dynamics in the absence of habit formation under the standard Taylor Rule, but not in the inertial Taylor Rule. Our findings oppose Nam's (2015)' because our open-economy section structure and risk sharing condition differ from Nam's model. While our model is based on a small open economy, Nam's model utilizes a twoopen economy model. Foreign marginal utility of consumption does not affect the real exchange rate in our model but does in Nam's model. Moreover, the international risk-sharing condition prevents the hump-shaped dynamics of consumption from affecting the dynamics of the real exchange rate in Nam's model, but not in our model. Thus, Nam's real exchange rate does not display hump-shaped dynamics.

The driving forces behind these dynamics can be summarized as follows: when a one percent persistent positive monetary policy shock hits the economy, the expected inflation rate and then, the contemporaneous inflation rate strongly decrease. Thus, the nominal interest rate decreases in the standard Taylor Rule. Since the decrease in the expected inflation rate is higher than the one in the nominal interest rate, the real interest rate increases. Through Euler dynamics, consumption declines. The presence of habit formation makes consumption more persistent. It is likely that while households instantaneously decrease consumption in response to monetary policy shock in the absence of habit formation, they slowly adjust to decrease in consumption in the presence of habit formation. More specifically, when habits indicate lower persistence (i.e. $h=0.30$ ), consumption slowly shrinks compared to the one in which habit persistence is absent because households' current consumption patterns are more affected by their past consumption in the presence of habit persistence. Otherwise, higher decrease in current consumption requires higher decrease in future consumption in the presence of habit persistence. If the requirement is not satisfied, marginal disutility arises. Thus, lower persistence leads households to smooth their consumption, and consumption slowly returns to its steady state following the shock. Thus, consumption displays quasi hump-shaped dynamics. Through the international risk-sharing condition, the real exchange rate also displays quasi hump-shaped dynamics. Conversely, in the model with higher habit persistence, households more sluggishly decrease consumption as a result of the shock. The reason behind this is that households' current consumption is considerably affected by their past consumption. Consumption and the real exchange rate thus display hump-shaped dynamics. These discussions are generalized for the inertial Taylor rule. However, since the inertia variable lends the model extra persistence, the effect of shock on the real exchange rate is higher under the inertial Taylor Rule.

Upon performing a sensitivity analysis, we find that changes in degree of openness, Calvo parameter and trend inflation rate do not significantly alter the dynamic response of the real exchange rate to different habit persistence parameters under the standard Taylor Rule. We then perform a robustness analysis by incorporating an incomplete market with portfolio adjustment cost into the model, finding that the real exchange rate displays similar dynamic behaviors except in initial periods as the benchmark model at different habit persistence parameters under the standard Taylor rule. It does this also with high habit persistence parameter $h=0.90$ under the inertial Taylor rule.

This paper is organized into sections. Section 2 describes the economic model. Section 3 log-linearizes the equations. Section 4 presents the calibration parameter values. Section 5 discusses how habit persistence parameter $h$ affects the dynamics of the real exchange rate. 
Section 6 compares the impulse response functions of the real exchange rate (both with and without habit formation) under alternative monetary policy rules. Section 7 performs a sensitivity analysis. Section 8 conducts a robustness analysis. Section 9 concludes the paper.

\section{Model}

This section follows Gali \& Monacelli (2005) in developing a small open economy, NewKeynesian model with external habit formation in Abel (1990), accounting for positive trend inflation rate $\pi$ and indexation parameter $\zeta$. The world economy comprises a continuum of small open economies. Any policy taken in such a small open economy does not affect the rest of the world. In each economy there is a continuum of households represented by a single household that supplies labor to firms and consumes a basket of consumer goods. This household can purchase a complete set of internationally traded, state-contingent securities. Friction only presents in the goods market. Intermediate firms follow Calvo's (1983) pricing rule. Variables without a subscript refer to the home economy, ones with the $i$ subscript refer to country $i$, and ones with a star superscript refer to the world economy. This section specifies and describes the model economy.

Habits are formed at the level of the aggregate consumption good. Utility is derived from the habit-adjusted composite consumption good $\tilde{C}_{t}$.

$$
\tilde{C}_{t}=C_{t}-h C_{t-1}
$$

where $C_{t}$ is the composite consumption index and $h$ is the habit persistence parameter.

\section{Households}

Each model economy has an identical household. This household maximizes the following utility function (Equation 2) subject to the budget constraints shown in Equation 3 with respect to $\tilde{C}_{t}, D_{t}^{d}$, and $N_{t}$ :

$$
\begin{gathered}
E_{t}\left(\sum_{t=0}^{\infty} \beta^{t} \frac{\left(\tilde{C}_{t}\right)^{1-\sigma}}{1-\sigma}-\frac{N_{t}^{1+\varphi}}{1+\varphi}\right) \\
P_{t} \tilde{C}_{t}+P_{t} \delta_{t}+D_{t}^{d}+e_{t} D_{t}^{f}=D_{t-1}^{d}\left(1+i_{t-1}\right)+D_{t-1}^{f}\left(1+i_{t-1}^{*}\right) e_{t}+W_{t} N_{t}
\end{gathered}
$$

$\beta$ : intertemporal discount factor

$N_{t}$ : labor supply

$W_{t}$ : nominal wage

$P_{t}$ : Consumer Price Index $(\mathrm{CPI})$

$D_{t}^{d}$ : a state-contingent nominal bond denominated in home currency paying an interest rate $i_{t}$ that is available for households to purchase

$D_{t}^{f}$ : a bond denominated in foreign currency paying an interest rate $i_{t}^{*}$ that is available for households to purchase

$e_{t}$ : home currency price of a unit of foreign currency

$\sigma:$ risk aversion parameter

$\varphi$ : inverse of the Frisch elasticity of labor supply

$E_{t}$ : expectation operator in time $t$ 
Under superficial habit $\delta_{t}$ equals $h C_{t-1}$. Households are taken $\delta_{t}$ as given.

Note that all composite consumption indices, all price indices, and all demand functions are the same as in Gali \& Monacelli (2005).

\section{Optimality Conditions}

$$
\begin{gathered}
\text { Euler Equation: } E_{t}\left[\left(\frac{\tilde{C}_{t+1}}{\tilde{C}_{t}}\right)^{\sigma}\right]=\beta\left(1+i_{t}\right) E_{t}\left(\frac{P_{t}}{P_{t+1}}\right) \\
\text { Labor Supply: }\left(\tilde{C}_{t}\right)^{\sigma} N_{t}^{\varphi}=\frac{W_{t}}{P_{t}}=w_{t}^{r}
\end{gathered}
$$

where $w_{t}^{r}$ is the real wage.

\section{Firms}

There is a continuum of intermediate-goods producers indexed by $j \in[0,1]$. Each firm produces differentiated goods using the identical production function:

$$
Y_{j, t}=A_{t} N_{j, t}
$$

$A_{t}=\rho_{a} A_{1}+e_{a, t}$ and denotes technology, $\rho_{a}<1$ is the persistence parameter.

Aggregating Equation 6 over $j$ yields:

$$
\int_{0}^{1} Y_{j, t} d j=\int_{0}^{1}\left(\frac{P_{H, j, t}}{P_{H, t}}\right)^{-\epsilon} d j Y_{t}=\int_{0}^{1} A_{t} N_{j, t} d j=A_{t} N_{t}
$$

where $Y_{j, t}=\left(\frac{P_{H, j, t}}{P_{H, t}}\right)^{-\epsilon} Y_{t}$ is demand function and $\epsilon$ is the elasticity of substitution between differentiated goods.

$$
Y_{t}=\frac{A_{t} N_{t}}{z_{t}}
$$

where $\int_{0}^{1}\left(\frac{P_{H, j, t}}{P_{H, t}}\right)^{-\epsilon} d j=z_{t}$ is the price dispersion.

\section{i.Aggregate Price Dynamics}

Each intermediate goods-producing firm follows the rule established by Calvo (1983) whereby each firm updates nominal price with a probability of $1-\theta$ and indexes its nominal price to the previous period CPI inflation rate with a probability of $\theta$. Aggregate price dynamics are shown below:

$$
P_{H, t}=\left[(1-\theta)\left(X_{t}\right)^{1-\epsilon}+\theta\left(\pi_{t-1}^{\zeta} P_{H, t-1}\right)^{1-\epsilon}\right]^{\frac{1}{1-\epsilon}}
$$


where $X_{t}$ is the reset price, $\zeta$ is the degree of indexation, and $P_{H, t}$ is the domestic price index. Note that $\pi_{H, t}=\frac{P_{H, t}}{P_{H, t-1}}$ is the domestic inflation rate in period $t$ and $\pi_{t}=\frac{P_{t}}{P_{t-1}}$ is the CPI inflation rate in period $t$.

\section{ii. Optimal Price Setting}

Intermediate firm $j$ chooses reset price $X_{t}$ to maximise the present value of its profit:

$$
\max _{X_{t}} \sum_{k=0}^{\infty} \theta^{k} E_{t}\left[\mathbb{Q}_{t, t+k}\left(X_{t} \Pi_{t-1, t+k-1}^{\zeta} Y_{j, t+k}-W_{t+k} N_{j, t+k}\right)\right]
$$

subject to the demand constraint: $Y_{j, t+k}=\left(\frac{x_{t} \Pi_{t-1, t+k-1}^{\zeta}}{P_{H, t+k}}\right)^{-\epsilon} Y_{t+k}$

where $\mathbb{Q}_{t, t+k}=\beta^{k}\left(\frac{\tilde{C}_{t+k}}{\tilde{C}_{t}}\right)^{-\sigma} \frac{P_{t}}{P_{t+k}}$ is the Stochastic Discount Factor and $\Pi_{t+k, t}$ is the cumulative CPI inflation rate between $t+k$ and $t$.

$$
x_{t}=\frac{\epsilon}{\epsilon-1} \frac{E_{t} \sum_{k=0}^{\infty}(\beta \theta)^{k} Y_{t+k} M C_{t+k}^{r}\left(\tilde{C}_{t+k}\right)^{-\sigma} \Pi_{H, t, t+k}^{\epsilon+1} \Pi_{t, t+k}^{-1} \Pi_{t-k, t+k-1}^{-\zeta \epsilon}}{E_{t} \sum_{k=0}^{\infty}(\beta \theta)^{k} Y_{t+k}\left(\tilde{C}_{t+k}\right)^{-\sigma} \Pi_{H, t, t+k}^{\epsilon} \Pi_{t, t+k}^{-1} \Pi_{t-k, t+k-1}^{\zeta(1-\epsilon)}}
$$

where $x_{t}=\frac{X_{t}}{P_{H, t}}$ is the real reset price, $M C_{t}^{r}=\frac{W_{t}}{P_{H, t} A_{t}}$ is the real marginal cost, and $\Pi_{H, t+k, t}$ is the cumulative domestic inflation rate between $t+k$ and $t$.

$$
x_{t}=\frac{\epsilon}{\epsilon-1} \frac{\psi_{t}}{\phi_{t}}
$$

where

$$
\psi_{t}=E_{t} \sum_{k=0}^{\infty}(\beta \theta)^{k} Y_{t+k} M C_{t+k}^{r}\left(\tilde{C}_{t+k}\right)^{-\sigma} \Pi_{H, t, t+k}^{\epsilon+1} \Pi_{t, t+k}^{-1} \Pi_{t-k, t+k-1}^{-\zeta \epsilon}
$$

and

$$
\phi_{t}=E_{t} \sum_{k=0}^{\infty}(\beta \theta)^{k} Y_{t+k}\left(\tilde{C}_{t+k}\right)^{-\sigma} \Pi_{H, t, t+k}^{\epsilon} \Pi_{t, t+k}^{-1} \Pi_{t-k, t+k-1}^{\zeta(1-\epsilon)}
$$

$\psi_{t}$ and $\phi_{t}$ are recursively re-written as follows:

$$
\begin{gathered}
\psi_{t}=Y_{t} M C_{t}^{r}\left(\tilde{C}_{t}\right)^{-\sigma}+\theta \beta \pi_{t}^{-\zeta \epsilon} E_{t}\left(\pi_{t+1}^{-1} \pi_{H, t+1}^{\epsilon+1} \psi_{t+1}\right) \\
\phi_{t}=Y_{t}\left(\tilde{C}_{t}\right)^{-\sigma}+\theta \beta \pi_{t}^{\zeta(1-\epsilon)} E_{t}\left(\pi_{t+1}^{-1} \pi_{H, t+1}^{\epsilon} \phi_{t+1}\right)
\end{gathered}
$$




\section{iii.Price Dispersion}

Following Schmitt-Grohe \& Uribe (2007), price dispersion $z_{t}=\int_{0}^{1}\left(\frac{P_{H, j, t}}{P_{H, t}}\right)^{-\epsilon} d j$ can be expanded to:

$$
z_{t}=(1-\theta)\left(x_{t}\right)^{-\epsilon}+\theta \pi_{H, t}^{\epsilon} \pi_{t-1}^{-\zeta \epsilon} z_{t-1}
$$

\section{Monetary Policy Rule}

The Central Bank follows the Taylor Rule as a monetary policy:

$$
\left(\frac{1+i_{t}}{1+\bar{l}}\right)=\left(\frac{1+i_{t}}{1+\bar{l}}\right)^{\rho_{i}}\left(\left(\frac{\pi_{t}}{\pi}\right)^{\phi_{\pi}}\left(\frac{Y_{t}}{Y}\right)^{\phi_{Y}}\right)^{1-\rho_{i}} \exp ^{v_{t}}
$$

where $v_{t}=\rho_{v} v_{t-1}+e_{v}$ is monetary policy shock and $\rho_{v}<1$ is the persistence parameter. $\phi_{\pi}$ and $\phi_{y}$ are coefficients of the variables in the monetary policy rule. $\rho_{i}$ is the rule's inertia coefficient. $\pi, Y$ and $\bar{l}$ are the steady state values of inflation rate, output and nominal interest rate. Note that $\rho_{i}=0$ implies the standard Taylor Rule and $\rho_{i}>0$ implies the inertial Taylor Rule.

\section{Indices, Assumptions, Definitions, and Identities}

In this section, some indices, assumptions, definitions, and identities are replicated as in Gali \& Monacelli (2005).

Domestic Price Index (i.e. an index of prices of domestically produced goods) is defined as:

$$
P_{H, t}=\left(\int_{0}^{1} P_{H, j, t}^{1-\epsilon} d j\right)^{\frac{1}{1-\epsilon}}
$$

Price Index for imported goods from country $i$ in terms of domestic currency is defined as:

$$
P_{i, t}=\left(\int_{0}^{1} P_{i, j, t}^{1-\epsilon} d j\right)^{\frac{1}{1-\epsilon}}
$$

Price Index for imported goods in terms of domestic currency is defined as:

$$
P_{F, t}=\left(\int_{0}^{1} P_{i, t}^{1-\gamma} d i\right)^{\frac{1}{1-\gamma}}
$$

where $\gamma$ is the substitutability between goods produced in different foreign countries.

Consumer Price Index (CPI) is defined as:

$$
P_{t}=\left[(1-\alpha) P_{H, t}^{1-\eta}+\alpha P_{F, t}^{1-\eta}\right]^{\frac{1}{1-\eta}}
$$


where $\alpha$ is trade openness and $\eta$ is the substitutability between domestic and foreign goods.

Bilateral Terms of Trade is defined as the ratio of the price index for imported goods from country $i$ in terms of domestic currency to the domestic price index.

$$
S_{i, t}=\frac{P_{i, t}}{P_{H, t}}
$$

The Terms of Trade are defined as the ratio of the price index for imported goods in terms of domestic currency to the domestic price index.

$$
S_{t}=\frac{P_{F, t}}{P_{H, t}}=\left(\int_{0}^{1} S_{i, t}^{1-\gamma} d i\right)^{\frac{1}{1-\gamma}}
$$

The Law of One Price holds for all individual goods.

$$
P_{i, j, t}=\varepsilon_{i, t} P_{i, j, t}^{i}
$$

where $P_{i, j, t}$ is the price of country $i$ 's good $j$ in terms of domestic currency, $P_{i, j, t}^{i}$ is the price of country $i$ 's goods $j$ in terms of country $i$ 's currency, and $\varepsilon_{i, t}$ is the bilateral nominal exchange rate between country $i$ and the domestic economy.

The Bilateral Real Exchange Rate is the ratio of country i's CPI to the domestic economy's CPI.

$$
Q_{i, t}=\frac{\varepsilon_{i, t} P_{i, t}^{i}}{P_{t}}
$$

where $P_{i, t}^{i}$ is the CPI for country $i$.

\section{Risk-Sharing Condition}

Following Gali \& Monacelli (2005), we obtained the following international risksharing condition:

$$
E_{t}\left[\frac{\left(\tilde{C}_{t+1}\right)}{\left(\tilde{C}_{t}\right)}\right]=E_{t}\left[\frac{\left(\tilde{C}^{i}{ }_{t+1}\right)}{\left(\tilde{C}^{i} t\right)}\left(\frac{Q_{i, t+1}}{Q_{i, t}}\right)^{\frac{1}{\sigma}}\right]
$$

where $\tilde{C}^{i}{ }_{t}$ is the habit-adjusted composite consumption index for country $i$. They derive this condition under the assumption of a complete financial market.

$$
\tilde{C}_{t}=\vartheta_{i, t} \tilde{C}_{t}^{i}\left(Q_{i, t}\right)^{\frac{1}{\sigma}}
$$

where $\vartheta_{i, t}$ is some constant. Without loss of generality, we assume symmetric initial conditions in all small open economies. Thus, $\vartheta_{i, t}=1$.

\section{Market-Clearing Condition}

Market-clearing condition is the same as in Gali \& Monacelli (2005): 


$$
Y_{t}=\left(\frac{P_{H, t}}{P_{t}}\right)^{-\eta} C_{t}\left[(1-\alpha)+\alpha \int_{0}^{1}\left(S_{t}^{i} S_{i, t}\right)^{\gamma-\eta} Q_{i, t}^{\eta-\frac{1}{\sigma}} d i\right]
$$

where $S_{t}^{i}$ represents the terms of trade for country $i$, while $S_{i, t}$ is the bilateral terms of trade between the home economy and country $i$.

\section{Uncovered Interest Rate Parity}

Households are allowed to invest in domestic and foreign bonds, respectively $D_{t}^{d}$ and $D_{t}^{f}$, under a complete international financial market. Optimization of these assets yields the following relation:

$$
\left(1+i_{t}\right)=\left(1+i_{t}^{*}\right) E_{t}\left(\frac{e_{t+1}}{e_{t}}\right)
$$

This relation is known as the uncovered interest rate parity condition.

\section{Log-linearization}

In this section, we display log-linear approximation of the model equations ${ }^{6}$. The hat variable implies log deviation of the variable from its steady state.

Log-linearizing Equation 1 yields:

$$
\hat{\tilde{c}}_{t}=\hat{c}_{t}-h \hat{c}_{t-1}
$$

Using Equation 28, log-linearizing the Euler Equation and labor supply in Equations 4 and 5 results in

$$
\begin{gathered}
E_{t}\left(\left(\hat{c}_{t+1}-h \hat{c}_{t}\right)-\left(\hat{c}_{t}-h \hat{c}_{t-1}\right)\right)=\frac{1}{\sigma} E_{t}\left(\hat{l}_{t}-\hat{\pi}_{t+1}\right) \\
\sigma\left(\hat{c}_{t}-h \hat{c}_{t-1}\right)+\varphi \hat{n}_{t}=\widehat{w}_{t}^{r}
\end{gathered}
$$

Log-linearization of Equation 7 yields the following equation:

$$
\hat{n}_{t}=\hat{y}_{t}-\hat{a}_{t}+\hat{z}_{t}
$$

Log-linearization of marginal cost is:

$$
\widehat{m c}^{r}{ }_{t}=\widehat{w}_{t}-\hat{p}_{H, t}-\hat{a}_{t}
$$

Log-linearization of the Calvo Pricing Rule in Equation 8 yields:

$$
\hat{x}_{t}=\frac{\theta \pi^{(\epsilon-1)(1-\zeta)}}{1-\theta \pi^{(\epsilon-1)(1-\zeta)}}\left(\hat{\pi}_{H, t}-\zeta \hat{\pi}_{t-1}\right)
$$

\footnotetext{
${ }^{6}$ The steady state values of variables are displayed in Appendix A.
} 
Log-linearizing Equations 11to 13 in the optimal price setting yields the following:

$$
\begin{gathered}
\hat{x}_{t}=\hat{\psi}_{t}-\hat{\phi}_{t} \\
\hat{\psi}_{t}=\left(1-\theta \beta \pi^{\epsilon(1-\zeta)}\right)\left(\widehat{m c}^{r}{ }_{t}+\hat{y}_{t}-\sigma\left(\hat{\tilde{c}}_{t}\right)\right)+\theta \beta \pi^{\epsilon(1-\zeta)} E_{t}\left(-\epsilon \zeta \hat{\pi}_{t}-\hat{\pi}_{t+1}\right. \\
\left.+(\epsilon+1) \hat{\pi}_{H, t+1}+\hat{\psi}_{t+1}\right) \\
\hat{\phi}_{t}=\left(1-\theta \beta \pi^{(\epsilon-1)(1-\zeta)}\right)\left(\hat{y}_{t}-\sigma \hat{\tilde{c}}_{t}\right)+\theta \beta \pi^{(\epsilon-1)(1-\zeta)} E_{t}\left((1-\epsilon) \zeta \hat{\pi}_{t}-\hat{\pi}_{t+1}\right. \\
\left.\left.+\epsilon \hat{\pi}_{H, t+1}+\hat{\phi}_{t+1}\right)\right)
\end{gathered}
$$

The log-linearized price dispersion is as follows:

$$
\hat{z}_{t}=-\epsilon\left(1-\theta \pi^{\epsilon(1-\zeta)}\right) \hat{x}_{t}+\theta \pi^{\epsilon(1-\zeta)}\left(-\epsilon \zeta \hat{\pi}_{t-1}+\epsilon \hat{\pi}_{H, t}+\hat{z}_{t-1}\right)
$$

Log-linearization of the CPI yields:

$$
\hat{p}_{t}=(1-\alpha) \hat{p}_{H, t}+\alpha \hat{p}_{F, t}
$$

Log-linearization of the terms of trade yields:

$$
\hat{s}_{t}=\hat{p}_{F, t}-\hat{p}_{H, t}
$$

Equations 38 and 39 yield the following relation:

$$
\hat{p}_{t}-\hat{p}_{H, t}=\alpha \hat{s}_{t}
$$

Using Equation 40 alongside the definitions of CPI inflation and domestic inflation results in the following relationship:

$$
\hat{\pi}_{t}=\hat{\pi}_{H, t}+\alpha \Delta \hat{s}_{t}
$$

We first substitute the Law of One Price into Equation 17 and then into Equation 18. Thereafter, it is log-linearized:

$$
\hat{p}_{F, t}=\hat{e}_{t}+\hat{p}_{t}^{*}
$$

where $\hat{e}_{t}=\int_{0}^{1} \hat{\varepsilon}_{i, t} d i$ is the nominal (effective) exchange rate and $\hat{p}^{*}{ }_{t}=\int_{0}^{1} \hat{p}_{i, t}^{i} d i$ is the world price index.

Equating Equations 39 and 42 yields the following expression:

$$
\hat{s}_{t}=\hat{e}_{t}+\hat{p}_{t}^{*}-\hat{p}_{H, t}
$$

First, we log-linearize the bilateral real exchange rate and then aggregate the obtained relation over $i$ : 


$$
\begin{gathered}
\hat{q}_{i, t}=\hat{\varepsilon}_{i, t}+\hat{p}_{i, t}^{i}-\hat{p}_{t} \\
\hat{q}_{t}=\int_{0}^{1}\left(\hat{\varepsilon}_{i, t}+\hat{p}^{i}{ }_{i, t}-\hat{p}_{t}\right) d i \\
\hat{q}_{t}=\hat{e}_{t}+\hat{p}_{t}^{*}-\hat{p}_{t}
\end{gathered}
$$

where $\hat{q}_{t}=\int_{0}^{1} \hat{q}_{i, t} d i$.

Using Equations 40, 43, and 44 yields the following relation:

$$
\hat{q}_{t}=(1-\alpha) \hat{s}_{t}
$$

Log-linearization of the market-clearing condition yields:

$$
\hat{y}_{t}=\hat{c}_{t}+\alpha \gamma \hat{s}_{t}+\alpha\left(\eta-\frac{1}{\sigma}\right) \hat{q}_{t}
$$

where $\int_{0}^{1} \hat{s}^{i}{ }_{t}=0$.

Using Equation 45, Equation 46 becomes:

$$
\begin{gathered}
\hat{y}_{t}=\hat{c}_{t}+\frac{\alpha \omega}{(1-\alpha) \sigma} \hat{q}_{t} \\
\omega=\sigma \gamma+(1-\alpha)(\sigma \eta-1)
\end{gathered}
$$

Equation 47 also holds for country $i$.

$$
\hat{y}_{t}^{i}=\hat{c}_{t}^{i}+\frac{\alpha \omega}{(1-\alpha) \sigma} \hat{q}_{t}^{i}
$$

Aggregating over $i$ yields the world market-clearing condition as follows:

$$
\int_{0}^{1} \hat{y}_{t}^{i} d i=\int_{0}^{1} \hat{c}^{i}{ }_{t} d i+\frac{\alpha \omega}{(1-\alpha) \sigma} \int_{0}^{1} \hat{q}_{t}^{i} d i
$$

Since $\int_{0}^{1} \hat{s}^{i}{ }_{t}=0$, the following expression results:

$$
\hat{y}_{t}^{*}=\hat{c}^{*}{ }_{t}
$$

Aggregating log-linearization of the international risk-sharing condition in Equation 25 yields:

$$
\left(\hat{c}_{t}-h \hat{c}_{t-1}\right)=\left(\hat{c}_{t}^{*}-h \hat{c}_{t-1}^{*}\right)+\frac{1}{\sigma} \hat{q}_{t}
$$

The log-linearized monetary policy rule is:

$$
\hat{\imath}_{t}=\rho_{i} \hat{\imath}_{t-1}+\left(1-\rho_{i}\right)\left(\phi_{\pi} \hat{\pi}_{t}+\phi_{y} \hat{y}_{t}\right)+v_{t}
$$


The log-linearized uncovered interest-rate parity condition is as follows:

$$
\hat{\imath}_{t}=\hat{\imath}^{*}+E_{t}\left(\hat{e}_{t+1}-\hat{e}_{t}\right)
$$

\section{Calibration}

This section presents calibration parameter values. The value of $\sigma=1.31, \eta=0.58$, and the Calvo parameter $\theta=0.79$ are taken from Justiniano \& Preston (2010); $\gamma$ is standard and set to 1. Trade openness is the ratio of imports to GDP, which is 0.215 for the Australian economy. ${ }^{7}$ Monetary policy rule parameters are standard: 1.5 for $\phi_{\pi}$ and $0.5 / 4$ for $\phi_{y}$. The persistence parameter for monetary policy shock $\rho_{v}$ is 0.85 . The elasticity of substitution between the differentiated goods $\epsilon$ is set to 6 as in Gibbs et al. (2018). The Reserve Bank of Australia targets a two percent inflation rate, thus trend inflation $\pi$ is set to two. For simplicity, labor is considered indispensable, and the indexation parameter is assumed to be zero. We set $\rho_{i}=0.85$ in the case of the inertial Taylor Rule.

\section{Analysis}

This section discusses whether habit persistence parameter $h$ affects the dynamics of the real exchange rate under the standard Taylor Rule. To facilitate this discussion, we make some simplifying assumptions: trend inflation $\pi$ is set to zero; inverse Frisch elasticity of labor supply $\varphi$ is set to zero; and $\sigma, \eta$ and $\gamma$ are assumed to be one. We set both $\phi_{\pi} \beta$ and $\phi_{y} \beta$ to 1 . To analyze how the habit persistence parameter affects the dynamics of the real exchange rate, the undetermined coefficient method is applied. We assume that shock hits the economy at period $t$. Note that $\hat{c}^{*}{ }_{t}=0$ and $\hat{a}_{t}=0$. Onwards, we deviate from the complete international risk sharing condition in Equation 50 to the one in Gali and Monacelli (2005). This eliminates the perfect risk sharing condition in our model section, leading to an ad-hoc time-varying risk sharing wedge. We call this model the benchmark model.

Using these simplifications, some of the above equations are rewritten to evaluate the effect of the habit persistence parameter on the dynamics of the real exchange rate:

The NKPC is

$$
\hat{\pi}_{H, t}=\kappa \widehat{m c}_{t}^{r}+\beta E_{t}\left(\hat{\pi}_{H, t+1}\right)
$$

where $\kappa=\frac{(1-\theta)(1-\theta \beta)}{\theta}$.

The Euler Equation is:

$$
E_{t}\left(\hat{\tilde{c}}_{t+1}-\hat{\tilde{c}}_{t}\right)=E_{t}\left(\hat{l}_{t}-\hat{\pi}_{t+1}\right)
$$

The labor supply is:

$$
\hat{\tilde{c}}_{t}=\widehat{w}^{r}
$$

The relation between real wage and marginal cost is:

\footnotetext{
${ }^{7}$ According to the ratio of imports to GDP for Australia in 2019 (Source: World Bank)
} 


$$
\widehat{m c}_{t}^{r}=\widehat{w}_{t}^{r}+\alpha \hat{s}_{t}
$$

The relation between the CPI inflation, Domestic Inflation, and Real Exchange Rate is:

$$
\hat{\pi}_{t}=\hat{\pi}_{H, t}+\frac{\alpha}{1-\alpha}\left(\hat{q}_{t}-\hat{q}_{t-1}\right)
$$

The market clearing condition is:

$$
\hat{y}_{t}=\hat{c}_{t}+\frac{\alpha}{1-\alpha} \hat{q}_{t}
$$

The International Risk-Sharing Condition becomes:

$$
\hat{c}_{t}=\hat{q}_{t}
$$

The standard Taylor Rule is:

$$
\hat{\imath}_{t}=\phi_{\pi} \hat{\pi}_{t}+\phi_{y} \hat{y}_{t}+v_{t}
$$

where $\phi_{\pi} \beta=1$ and $\phi_{y} \beta=1$.

The solution to the real exchange rate is the following equation:

$$
\hat{q}_{t}=\psi_{1} \hat{q}_{t-1}+\psi_{2} v_{t}
$$

where $\psi_{1}$ and $\psi_{2}$ are the coefficients of the real exchange rate's inertial variable and monetary policy shock, respectively.

Using Equations 53 to 61 we derive the dynamics of real exchange rate. ${ }^{8}$

$$
\hat{q}_{t}=\left[\frac{\left(\beta h+\frac{\alpha}{1-\alpha}+\kappa h\right)}{\Lambda-\frac{\beta}{(1-\alpha)} \psi_{1}} \hat{q}_{t-1}+\frac{\frac{\beta}{1-\alpha} \psi_{2} \rho_{v}-\beta}{\Lambda-\frac{\beta}{(1-\alpha)} \psi_{1}} v_{t}\right]
$$

where $\Lambda=\frac{(\alpha+\beta \alpha+\kappa)+\beta(1+h)(1-\alpha)+1}{1-\alpha}$.

Equation 62 indicates that habit persistence parameter $h$ affects the real exchange rate dynamics through two channels: first via coefficient $\psi_{1}$ of the real exchange rate's backwardlooking variable, and second via coefficient $\psi_{2}$ by affecting the impact of monetary policy shock on the real exchange rate. It is no longer possible to show $\psi_{1}$ and $\psi_{2}$ in a simple manner. Thus, we show the values of $\psi_{1}$ and $\psi_{2}$ numerically. In addition to the above simplifications, we set $\alpha=0.20$ and $\rho_{v}=0$. The rest of the parameters are the same as in the calibration parameter values. For a better understanding of these two channels, Figures 1-(a) and 1-(b) plot how coefficients $\psi_{1}$ and $\psi_{2}$ respond to changes in the habit persistence parameter in the case of

\footnotetext{
${ }^{8}$ For a detailed analytical derivation, see Appendix B.
} 
Figure 1 How Coefficients $\psi_{1}$ and $\psi_{2}$ Respond to Habit Persistence Parameter $h$

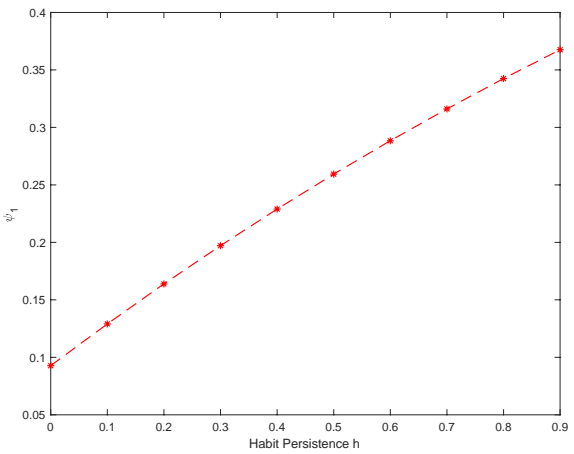

(a) Coefficient $\psi_{1}$

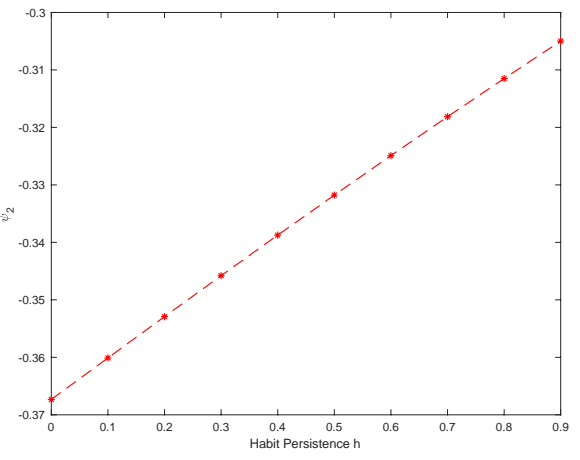

(b) Coefficient $\psi_{2}$

a one percent positive monetary policy shock under the standard Taylor Rule. As habit persistence parameter $h$ increases, coefficient $\psi_{1}$ likewise increases. This means that a higher habit persistence leads to more persistent real exchange rate dynamics. On the other hand, a higher habit-persistence parameter $h$ decreases the impact effect of monetary policy shock on real exchange rate dynamics in absolute terms.

\section{Hump-Shaped Real Exchange Rate}

This section aims to compare the dynamics of our model's real exchange rate at different habit persistence parameters in the benchmark model and to discuss the reasons behind these dynamics in the case of a one percent persistent positive monetary policy shock under two alternative monetary policy rules-the standard and inertial Taylor Rules.

Figure 2 presents the impulse response functions (IRFs) of the real exchange rate for different habit persistence parameters in response to a one percent persistent positive monetary policy shock under the standard Taylor Rule. The shock produces hump-shaped dynamics in the real exchange rate with habit persistence $h=0.90$, but it goes quasi hump-shaped in the models with habit persistence $h=0,0.30$ and 0.60 . While the real exchange rate reaches its bottom at Quarter 2 in the model with habit persistence $h=0$, it reaches its bottom at Quarters 3,3 , and 4 in the models with persistence $h=0.30,0.60$ and 0.90 , respectively. These dynamics are consistent with discussions in the previous section.

Figure 2 IRF of the Real Exchange Rate in Response to Persistent Monetary Policy Shock under the Standard Taylor Rule

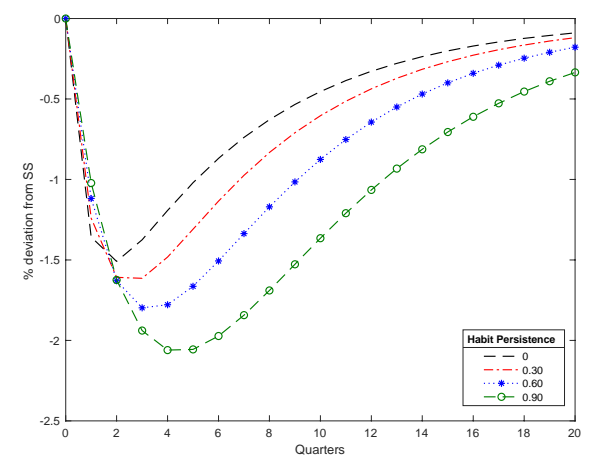

Figure 3 IRF of the Real Exchange Rate in Response to Persistent Monetary Policy Shock under the Inertial Taylor Rule

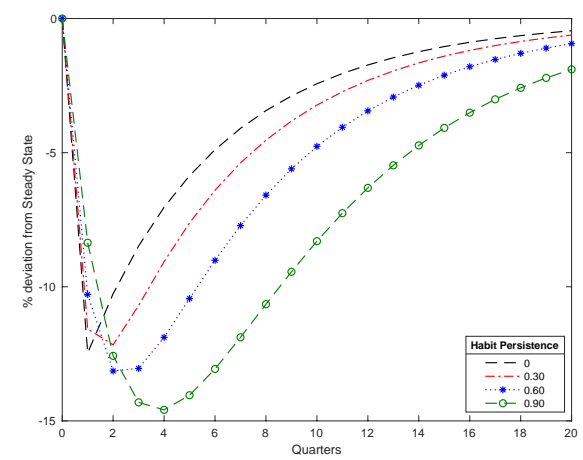

The reasons behind these dynamics can be summarized as follows: when a one percent persistent positive monetary policy shock hits the economy, the real interest rate increases and 
leads to a decrease in consumption. When habits indicate lower persistence (i.e. $h=0.30$ ), households smooth their consumption and slowly adjust to decrease their consumption. Consumption dynamics are thus quasi hump-shaped. Through the international risk-sharing condition, the real exchange rate also displays quasi hump-shaped dynamics. In the model with considerably higher habit persistence (i.e. $h=0.90$ ), households more sluggishly adjust consumption. Through the international risk-sharing condition, the real exchange rate also displays hump-shaped dynamics.

Figure 3 presents the IRFs of the real exchange rate for different habit persistence parameters in response to a one percent persistent positive monetary policy shock under the inertial Taylor Rule. The model with habit persistence $h=0.90$ leads to hump-shaped real exchange dynamics, while the models with habit persistence $h=0.30$ and 0.60 lead to a quasihump-shaped real exchange rate. Following the shock, the real exchange rate monotonically returns to its steady state in the model with habit persistence $h=0$. The models with habit persistence $h=0.30,0.60$ and 0.90 reach their bottoms in Quarters 2, 2 and 4, respectively. However, the non-habit-formation model reaches its bottom in Quarter 1. Compared to the standard Taylor Rule, under the inertial Taylor Rule the effect of shock on the real exchange rate is higher at different habit persistence parameters. Moreover, the impact effect of shock on the real exchange rate decreases at a higher habit persistence parameter under both types of monetary policy rules. This is in line with the discussions in the previous section.

\section{Sensitivity Analysis}

In this section, we perform a sensitivity analysis under different degree of openness, Calvo parameters, trend inflation rates and degree of inflation indexation under the standard Taylor Rule. Figure 4 presents the period at which the real exchange rate reaches its bottom across different habit persistence parameters under four cases with different degree of openness: 0.10 , $0.215,0.30$ and 0.40 under the standard Taylor Rule. Figure 5 presents the period at which the real exchange rate reaches its bottom across different habit persistence parameters under three cases with different Calvo Parameters 0.70, 0.79 and 0.85 under the standard Taylor Rule. Figure 6 presents the period at which the real exchange rate reaches its bottom across different habit persistence parameters under three cases with different trend inflation rates $0 \%, 2 \%$, and $4 \%$ under the standard Taylor Rule. Figure 7 presents the period at which the real exchange rate reaches its bottom across different habit persistence parameters under three cases with different degrees of inflation indexation: 0, 0.50, and 1 under the standard Taylor Rule.

Figure 4 At Which Period the Real Exchange Rate Reaches its Bottom Across Different Habit Persistence Parameters Under Four Cases with Different Degrees of Openness

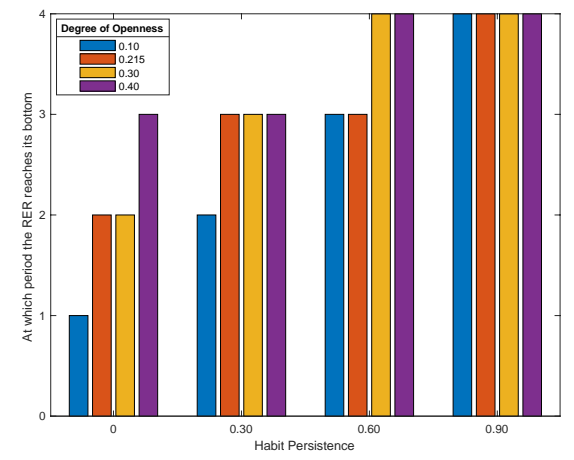

Figure 5 At Which Period the Real Exchange Rate Reaches its Bottom Across Different Habit Persistence Parameters Under Three Cases with Different Calvo Parameters

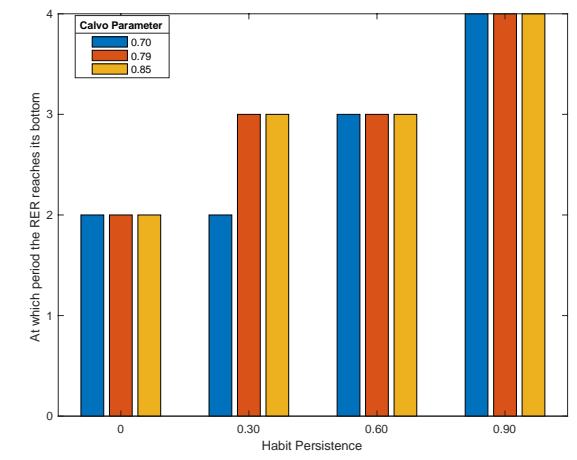


Figure 6 At Which Period the Real Exchange Rate Reaches its Bottom Across Different Habit Persistence Parameters Under Three Cases with Different Trend Inflation

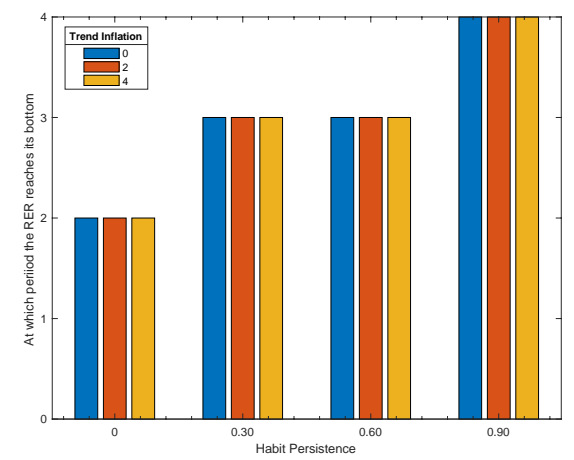

Figure 7 At Which Period the Real Exchange Rate Reaches its Bottom Across Different Habit Persistence Parameters Under Three Cases with Different Degrees of Inflation Indexation

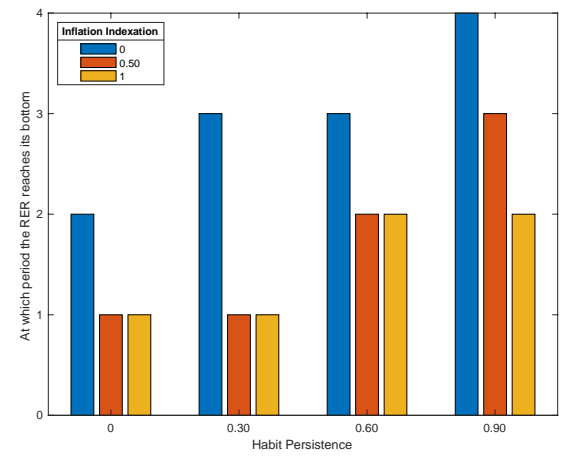

In Figure 4, the case with $\alpha=0.215$ corresponds to the case in the previous section under the standard Taylor Rule. In Figure 5, the case with $\theta=0.79$ corresponds to the case in the previous section under the standard Taylor Rule. In Figure 6, the case with $\pi=2$ corresponds to the case in the previous section under the standard Taylor Rule. In Figure 7, the case with $\zeta=0$ corresponds to the case in the previous section under the standard Taylor Rule. Sensitivity analysis indicates that changes in degree of openness, Calvo parameter, and trend inflation rate do not significantly affect when the real exchange rate hits its bottom at different habit persistence parameters. However, a change in degree of inflation indexation alters when the real exchange rate hits its bottom at different habit persistence parameters.

\section{Robustness ${ }^{9}$}

Figures 8 and 9 present the IRFs of monetary policy shock in the model featuring an incomplete market with portfolio adjustment cost under alternative monetary policy rules, the standard Taylor Rule, and the inertial Taylor Rule, respectively. In this model, the real exchange rate displays similar behavior except in initial periods as in the benchmark model at all different habit persistence parameters (high habit persistence parameter) under the standard Taylor rule (the inertial Taylor rule $)^{10}$.

Figure 8 IRF of the Real Exchange Rate in Response to Persistent Monetary Policy Shock under the Standard Taylor Rule

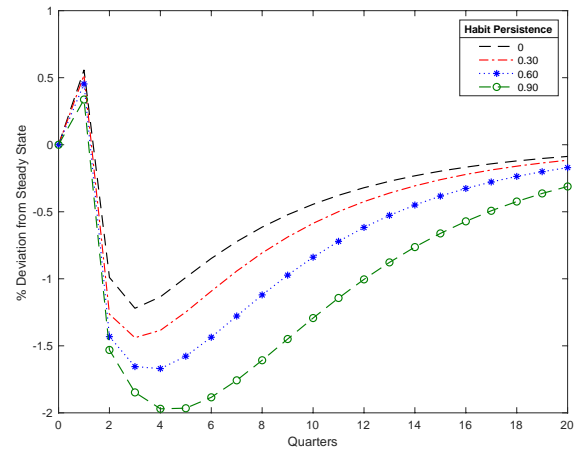

Figure 9 IRF of the Real Exchange Rate in Response to Persistent Monetary Policy Shock under the Inertial Taylor Rule

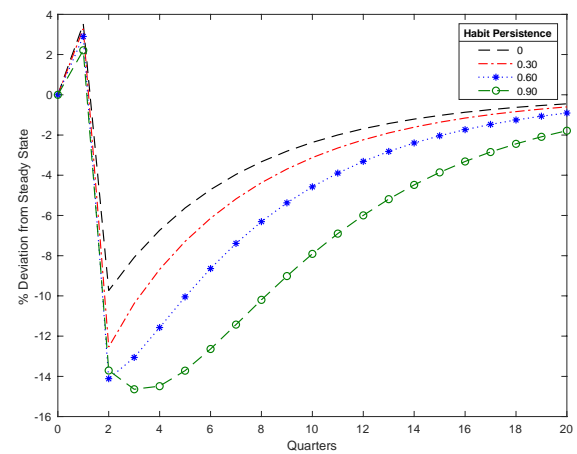

\footnotetext{
${ }^{9}$ See Appendix $\mathrm{C}$ for the different parts of the model featuring an incomplete market with portfolio adjustment cost.

${ }^{10}$ The reason why the real exchange rate sharply increases in initial periods under both rules arises from the uncovered parity condition.
} 


\section{Conclusion}

This paper studies the effect of habit persistence parameter $h$ on the dynamics of the real exchange rate in a New-Keynesian model with a positive trend inflation assumption under alternative monetary policy rules (the standard Taylor Rule and the inertial Taylor Rule) in an incomplete model with a risk-sharing wedge. We analytically show that habit persistence parameter $h$ has an impact on both the persistence of the real exchange rate and the impact effect of monetary policy shock. The impulse response function of the real exchange rate is humpshaped in the standard and inertial Taylor Rules when habit formation is considerably high. In the moderately high and low habit persistence parameters, it displays quasi-hump-shaped dynamics under both rules. However, it is quasi hump-shaped in the absence of habit formation in the standard Taylor Rule, but not in the inertial Taylor Rule. Our robustness analysis indicates that the model with an incomplete market with portfolio adjustment cost displays similar effects of habit persistence parameter $h$ on real exchange rate dynamics except in initial periods under the standard Taylor rule as in the benchmark model. 


\section{References}

Abel, A. B. (1990). "Asset Prices under Habit Formation and Catching Up with the Joneses", The American Economic Review Papers and Proceedings, 80, 38-42.

Ascari, G., Ropele, T. (2009). "Trend Inflation, Taylor Principle, and Indeterminacy," Journal of Money, Credit and Banking, 41(8), 1557-1584.

Ascari, G., Sbordone, A. (2014). "The Macroeconomics of Trend Inflation," Journal of Economic Literature, 52(3), 679-739.

Benigno, G., (2004). "Real Exchange Rate Persistence and Monetary Policy Rules," Journal of Monetary Economics, 51, 473-502.

Berger, D., Bocola, L., \& Dovis, A. (2019) "Imperfect Risk-Sharing and the Business Cycle," NBER Working Papers, No 26032, Available at: https://www.nber.org/system/files/working_papers/w26032/w26032.pdf

Calvo, G. A., (1983). "Staggered prices in a utility-maximising framework," Journal of Monetary Economics. 12, 383-398.

Carvalho, C., Nechio, F., (2011). "Aggregation and the PPP Puzzle in a Sticky-Price Model," American Economic Review, 101 (6), 2391-2424.

Chari, V. V., Kehoe, P., Mcgratten, E., (2002). "Can Sticky Price Models Generate Volatile and Persistent Real Exchange Rates?," Review of Economic Studies, 69, 533-563.

Cheung, Y., Lai, K. S., (2000). "On the purchasing power parity puzzle," Journal of International Economics, 52(2), 321-330.

Cooke, D., Kara, E. (2018). "Can Trend Inflation Solve the Delayed Overshooting Puzzle?," Globalization and Monetary Policy Institute Working Paper No. 334. Available at SSRN: https://ssrn.com/abstract=3119599 or http://dx.doi.org/10.24149/gwp334.

Eichenbaum, M., Evans, C., (1995). "Some Empirical Evidence on the Effects of Shocks to Monetary Policy on Exchange Rates," The Quarterly Journal of Economics, 110(4), 975-1009.

Engel, C., (2019). "Real exchange rate convergence: The roles of price stickiness and monetary policy," Journal of Monetary Economics, 103, 21-32.

Gali, J., Monacelli, T. (2005). "Monetary Policy and Exchange Rate Volatility in a Small Open Economy," Review of Economic Studies, 72(3), 707-734.

Gibbs, C.G., Hambur, J., Nodari, G. (2018). "DSGE Reno: Adding a Housing Block to a Small Open Economy Model," Reserve Bank of Australia, Research Discussion Papers No: 2018-04, Available at: https://www.rba.gov.au/publications/rdp/2018/pdf/rdp201804.pdf

Grilli, V., Roubini, N., (1996). "Liquidity Models in Open Economies: Theory and Empirical Evidence," European Economic Review, 40, 847-859.

Huizinga, J., (1987). "An empirical investigation of the long-run behaviour of real exchange rates," Carnegie-Rochester Conference Series on Public Policy, 27(1), 149-214.

Justiniano, A., Preston, B., (2010). "Monetary policy and uncertainty in an empirical small open economy model," Journal of Applied Econometrics, 25(1), 93-128.

Kim, SH., Moon, S., Velasco, C. (2017). "Delayed Overshooting: Is It an 80s Puzzle?," Journal of Political Economy, 125, 1570-1598.

Nam, D., (2015). "Habit formation, asymmetric price adjustment, and real exchange rate persistence," Journal of Economic Research, 20, 83-116.

Rogoff, K., (1996). “The Purchasing Power Parity Puzzle," Journal of Economic Literature, 34, 647-68.

Schmitt-Grohé, S., Uribe, M. (2007). "Optimal inflation stabilization in a medium- scale macroeconomic model," In Monetary Policy Under Inflation Targeting, K. SchmidtHebbel and R. Mishkin (Eds.), 125-186. Santiago, Chile: Central Bank of Chile. 
Scholl, H., Uhlig, H. (2008). "New evidence on the puzzles: Results from agnostic identification on monetary policy and exchange rates," Journal of International Economics, 76, 1-13.

Steinsson, J., (2008). "The Dynamic Behavior of the Real Exchange Rate in Sticky Price Models," American Economic Review, 98 (1), 519-33. 


\section{Appendix A}

In this appendix, we indicate the steady state values of the variables.

\begin{tabular}{c|c} 
Variable & Value \\
\hline $\mathrm{Y}$ & 0.3328 \\
$\mathrm{C}$ & 0.3328 \\
$\mathrm{~A}$ & 1 \\
$\mathrm{~N}$ & 0.3333 \\
$\mathrm{i}$ & 0.0151 \\
$\mathrm{Z}$ & 1.0016 \\
$\mathrm{~S}$ & 1 \\
$\mathrm{Q}$ & 1 \\
$\mathrm{MC}$ & 0.8329 \\
$\mathrm{w}^{\mathrm{r}}$ & 0.8329 \\
$\mathrm{X}$ & 1.020 \\
$\psi$ & 7.0924 \\
$\phi$ & 6.0286 \\
$\mathrm{e}$ & 1 \\
$\pi$ & 1.005 \\
$\pi_{H}$ & 1.005 \\
$\tilde{C}$ & $0.3328(1-h)$ \\
\hline
\end{tabular}

\section{Appendix B}

In this section, to derive the dynamics of the real exchange rate with some simplifying assumptions, we repeat some equations with zero trend inflation rate assumption, $\sigma, \gamma$ and $\eta=$ 1 , and $\varphi=0$. To be able to perform an analytical discussion for the incomplete market, we return to the international risk sharing condition in Gali and Monacelli (2005). It provides incompleteness to our model.

The NKPC is as follows:

$$
\hat{\pi}_{H, t}=\kappa \widehat{m c}_{t}^{r}+\beta E_{t}\left(\hat{\pi}_{H, t+1}\right)
$$

where $\kappa=\frac{(1-\theta)(1-\theta \beta)}{\theta}$.

The International risk sharing condition is:

$$
\widehat{c_{t}}-\widehat{c_{t}^{*}}=\widehat{q}_{t}
$$

The Euler Equation is:

$$
E_{t}\left(\hat{\tilde{c}}_{t+1}-\hat{\tilde{c}}_{t}\right)=E_{t}\left(\hat{\imath}_{t}-\hat{\pi}_{t+1}\right)
$$

The Labor Supply Equation is:

$$
\left(\hat{c}_{t}-h \hat{c}_{t-1}\right)=\widehat{w}_{t}^{r}
$$


The relation among CPI inflation, domestic inflation, and terms of trade is:

$$
\hat{\pi}_{t}=\hat{\pi}_{H, t}+\alpha \Delta \hat{s}_{t}
$$

The relation between the real exchange rate and terms of trade is:

$$
\hat{q}_{t}=(1-\alpha) \hat{s}_{t}
$$

The Market Clearing Condition is:

$$
\hat{y}_{t}=\hat{c}_{t}+\frac{\alpha}{1-\alpha} \hat{q}_{t}
$$

The Marginal Cost is:

$$
\widehat{m c}_{t}^{r}=\widehat{w}_{t}-\hat{p}_{H, t}-\hat{a}_{t}
$$

Since $\hat{c}^{*}{ }_{t}=0$, Equation B.2 becomes:

$$
\hat{c}_{t}=\hat{q}_{t}
$$

Substituting Equation B.9 into Euler Equation:

$$
E_{t}\left(\hat{q}_{t+1}\right)-(1+h) \hat{q}_{t}+h \hat{q}_{t-1}=\hat{\imath}_{t}-E_{t}\left(\hat{\pi}_{t+1}\right)
$$

The standard Taylor Rule is:

$$
\hat{\imath}_{t}=\phi_{\pi} \hat{\pi}_{t}+\phi_{y} \hat{y}_{t}+v_{t}
$$

Equation B.8 is extended:

$$
\begin{gathered}
\widehat{m c}^{r}{ }_{t}=\left(\widehat{w}_{t}-\hat{p}_{t}\right)+\left(\hat{p}_{t}-\hat{p}_{H, t}\right)-\hat{a}_{t} \\
\widehat{m c}^{r}{ }_{t}=\left(\widehat{w}_{t}^{r}\right)+\left(\hat{p}_{t}-\hat{p}_{H, t}\right)-\hat{a}_{t}
\end{gathered}
$$

Substituting Equation B.4 and $\hat{p}_{t}-\hat{p}_{H, t}=\alpha \hat{s}_{t}$ into Equation B.12 yields:

$$
\widehat{m c}_{t}^{r}=\left(\hat{c}_{t}-h \hat{c}_{t-1}\right)+\alpha \hat{s}_{t}-\hat{a}_{t}
$$

Using the international risk-sharing condition and $\hat{q}_{t}=(1-\alpha) \hat{s}_{t}$, Equation B.13 is:

$$
\widehat{m c}_{t}^{r}=\frac{1}{1-\alpha}\left(\hat{q}_{t}\right)-h \hat{q}_{t-1}-\hat{a}_{t}
$$

Note that $\hat{a}$ is set to 0 :

$$
\widehat{m c}_{t}^{r}=\frac{1}{1-\alpha}\left(\hat{q}_{t}\right)-h \hat{q}_{t-1}
$$

Using $\hat{q}_{t}=(1-\alpha) \hat{s}_{t}$, Equation B.5 becomes: 


$$
\hat{\pi}_{t}=\hat{\pi}_{H, t}+\frac{\alpha}{1-\alpha}\left(\hat{q}_{t}-\hat{q}_{t-1}\right)
$$

Substituting Equation B.14 into the NKPC:

$$
\hat{\pi}_{H, t}=\kappa \frac{1}{1-\alpha} \hat{q}_{t}-\kappa h \hat{q}_{t-1}+\beta E_{t}\left(\hat{\pi}_{H, t+1}\right)
$$

Then, plugging Equation B.15 into B.16:

$$
\begin{gathered}
\hat{\pi}_{t}-\frac{\alpha}{1-\alpha}\left(\hat{q}_{t}-\hat{q}_{t-1}\right)=\kappa \frac{1}{1-\alpha}\left(\hat{q}_{t}\right)-\kappa h \hat{q}_{t-1}+\beta E_{t}\left(\hat{\pi}_{t+1}-\frac{\alpha}{1-\alpha}\left(\hat{q}_{t+1}-\hat{q}_{t}\right)\right) \\
\hat{\pi}_{t}-\beta E_{t}\left(\hat{\pi}_{t+1}\right)=-\left(\frac{\alpha}{1-\alpha}+\kappa h\right) \hat{q}_{t-1}+\frac{\alpha+\beta \alpha+\kappa}{1-\alpha} \hat{q}_{t}-\frac{\beta \alpha}{1-\alpha} E_{t}\left(\hat{q}_{t+1}\right)
\end{gathered}
$$

Multiplying Equation B.11 by $\beta$ :

$$
\beta \hat{\imath}_{t}=\beta \phi_{\pi} \hat{\pi}_{t}+\beta \phi_{y} \hat{y}_{t}+\beta v_{t}
$$

Assume that $\beta \phi_{\pi}$ and $\beta \phi_{y}$ are 1:

$$
\beta \hat{\imath}_{t}=\hat{\pi}_{t}+\hat{y}_{t}+\beta v_{t}
$$

Multiplying Equation B.10 by $\beta$ yields:

$$
\beta \hat{\imath}_{t}=\beta E_{t}\left(\hat{q}_{t+1}-(1+h) \hat{q}_{t}+h \hat{q}_{t-1}\right)+\beta E_{t}\left(\hat{\pi}_{t+1}\right)
$$

Plugging Equation B.18 into Equation B.19 yields:

$$
\hat{\pi}_{t}-\beta E_{t}\left(\hat{\pi}_{t+1}\right)=\beta E_{t}\left(\hat{q}_{t+1}-(1+h) \hat{q}_{t}+h \hat{q}_{t-1}\right)-\hat{y}_{t}-\beta v_{t}
$$

Equating Equations B.17 and B.20 yields:

$$
\begin{aligned}
& \hat{q}_{t}=\frac{1-\alpha}{(\alpha+\beta \alpha+\kappa)+\beta(1+h)(1-\alpha)}\left[\left(\beta h+\frac{\alpha}{1-\alpha}+\kappa h\right) \hat{q}_{t-1}\right. \\
& \left.+\frac{\beta}{1-\alpha} E_{t}\left(\hat{q}_{t+1}\right)-\hat{y}_{t}-\beta v_{t}\right]
\end{aligned}
$$

Substitute Equation B.9 for Equation B.7:

$$
\hat{y}_{t}=\frac{1}{1-\alpha} \hat{q}_{t}
$$

Plugging Equation B.22 into B.21 yields:

$$
\begin{gathered}
\hat{q}_{t}=\frac{1-\alpha}{(\alpha+\beta \alpha+\kappa)+\beta(1+h)(1-\alpha)+1}\left[\left(\beta h+\frac{\alpha}{1-\alpha}+\kappa h\right) \hat{q}_{t-1}\right. \\
\left.+\frac{\beta}{1-\alpha} E_{t}\left(\hat{q}_{t+1}\right)-\beta v_{t}\right]
\end{gathered}
$$




$$
\hat{q}_{t}=\frac{1}{\Lambda}\left[\left(\beta h+\frac{\alpha}{1-\alpha}+\kappa h\right) \hat{q}_{t-1}+\frac{\beta}{1-\alpha} E_{t}\left(\hat{q}_{t+1}\right)-\beta v_{t}\right]
$$

where $\Lambda=\frac{(\alpha+\beta \alpha+\kappa)+\beta(1+h)(1-\alpha)+1}{1-\alpha}$.

The solution to the real exchange rate is the following equation:

$$
\hat{q}_{t}=\psi_{1} \hat{q}_{t-1}+\psi_{2} v_{t}
$$

where $\psi_{1}$ and $\psi_{2}$ are the coefficients of the inertial variable of the real exchange rate and monetary policy shock.

$$
\hat{q}_{t}=\left[\frac{\left(\beta h+\frac{\alpha}{1-\alpha}+\kappa h\right)}{\Lambda-\frac{\beta}{(1-\alpha)} \psi_{1}} \hat{q}_{t-1}+\frac{\frac{\beta}{1-\alpha} \psi_{2} \rho_{v}-\beta}{\Lambda-\frac{\beta}{(1-\alpha)} \psi_{1}} v_{t}\right]
$$

\section{Appendix C}

In this appendix, the incomplete market feature is incorporated into the model. Household and international risk-sharing sections differ from the model previously developed in this paper, but other aspects are identical. The incomplete market stems from portfolio adjustment costs.

\section{Households} function:

In every economy there is an identical household that maximizes the following utility

$$
E_{t}\left(\sum_{t=0}^{\infty} \beta^{t} \frac{\left(C_{t}-h C_{t-1}\right)^{1-\sigma}}{1-\sigma}-\frac{N_{t}^{1+\varphi}}{1+\varphi}\right)
$$

subject to the budget constraint shown in Equation C.2.

$$
P_{t} C_{t}+D_{t}^{d}+e_{t} D_{t}^{f}+A C_{D^{f}, t}=D_{t-1}^{d}\left(1+i_{t-1}\right)+D_{t-1}^{f}\left(1+i_{t-1}^{*}\right) e_{t}+W_{t} N_{t}
$$

where $\beta$ is the intertemporal discount factor, $C_{t}$ is the composite consumption index, $N_{t}$ is labor supply, $W_{t}$ is nominal wage, and $P_{t}$ is the consumer price index. Households can purchase a non-contingent nominal bond $D_{t}^{d}$ denominated in home currency paying interest rate $i_{t}$ and a bond denominated in foreign currency $D_{t}^{f}$ paying interest rate $i_{t}^{*} . e_{t}$ is the home currency price of a unit of foreign currency, $h$ is the persistence coefficient of habit formation, $\sigma$ is the risk aversion parameter, $\varphi$ is the inverse Frisch elasticity of labor supply, and $E_{t}$ is the expectation operator in time $t$. There is a small adjustment cost of $A C_{D^{f}, t}=\frac{\psi_{D} f\left(e_{t}\left(D_{t}^{f}-D^{f}\right)^{2}\right)}{2 P_{H, t} Y_{t}}$ on bond holdings where $P_{H, t}$ is the domestic price level, $Y_{t}$ is output, and $D^{f}$ is the steady state value of foreign bonds.

\section{Optimality Conditions}

$$
\text { Euler Equation: }\left(\frac{C_{t+1}-h C_{t}}{C_{t}-h C_{t-1}}\right)^{\sigma}=\beta\left(1+i_{t}\right) \frac{P_{t}}{P_{t+1}}
$$




$$
\text { Labour Supply: }\left(C_{t}-h C_{t-1}\right)^{\sigma} N_{t}^{\varphi}=\frac{W_{t}}{P_{t}}=w_{t}^{r}
$$

where $w_{t}^{r}$ is the real wage.

$$
\begin{aligned}
& \text { Interest Rate Parity Condition: }\left(1+i_{t}\right) \\
& \qquad=\left(1+i_{t}^{*}\right) \frac{e_{t+1}}{e_{t}}\left(1+\frac{\psi_{D}^{f}\left(D_{t}^{f}-D^{f}\right)}{P_{H, t} Y_{t}}\right)^{-1}
\end{aligned}
$$

where $D^{f}$ is the steady state value of foreign bond.

\section{The Risk-Sharing Condition}

This paper deviates from the standard international risk-sharing condition in Gali \& Monacelli (2005) by incorporating the real exchange rate definition and the interest rate parity condition into the above equation:

$$
\frac{\left(C_{t+1}-h C_{t}\right)}{\left(C_{t}-h C_{t-1}\right)}=\frac{\left(C_{t+1}^{*}-h C_{t}^{*}\right)}{\left(C_{t}^{*}-h C_{t-1}^{*}\right)}\left(\frac{Q_{t+1}}{Q_{t}}\right)^{\frac{1}{\sigma}} \Psi_{t}
$$

where $\Psi_{t}$ is an auxiliary variable. 